Portland State University

PDXScholar

Civil and Environmental Engineering Master's

Project Reports

Summer 2019

\title{
Test Setup Design and Cyclic Evaluation of Rocking CLT Wall and Floor Restoring Force Lateral System
}

Aaron Davis Smith

Portland State University

Follow this and additional works at: https://pdxscholar.library.pdx.edu/cengin_gradprojects

Part of the Civil Engineering Commons, and the Construction Engineering and Management

Commons

Let us know how access to this document benefits you.

\section{Recommended Citation}

Smith, Aaron Davis, "Test Setup Design and Cyclic Evaluation of Rocking CLT Wall and Floor Restoring Force Lateral System" (2019). Civil and Environmental Engineering Master's Project Reports. 46. https://doi.org/10.15760/CCEMP.46

This Project is brought to you for free and open access. It has been accepted for inclusion in Civil and Environmental Engineering Master's Project Reports by an authorized administrator of PDXScholar. Please contact us if we can make this document more accessible: pdxscholar@pdx.edu. 
Test Setup Design and Cyclic Evaluation of Rocking CLT Wall and Floor Restoring Force Lateral System

\title{
BY
}

\author{
Aaron D. Smith
}

\begin{abstract}
A research project report submitted in partial fulfillment of the requirement for the degree of
\end{abstract}

\section{MASTER OF SCIENCE \\ IN \\ CIVIL AND ENVIRONMENTAL ENGINEERING}

Project Advisor:

Faculty Name

Portland State University

(C)2019 


\section{ACKNOWLEDGMENTS}




\begin{abstract}
The introduction of the demand for mass timber buildings in are with seismic hazard areas has called for new lateral systems. Lateral systems in mass timber building typically utilize a rocking shear wall with post-tensioned rods to provide system re-centering. These post-tensioned rods add axial load to the shear wall and potentially endure long term creep affects. Mass Timber buildings consist of cross laminated (clt) shear walls and floor slabs along with glulam beams. The flexural capacity of the CLT floor slabs along with dead load can provide an alternative source for the restoring force. This project developed a test setup to accommodate a full scale cyclic testing of this restoring force. Cyclic testing included determining the influence of dead load on the system and the influence of ductile hold-downs. Hold-downs properties can be varied to alter shape of the hysteretic curve and to allow recentering. The hold-downs will serve as sacrificial fuses with the goal all yielding occurs to them while mass timber members remain elastic.
\end{abstract}




\section{TABLE OF CONTENTS}

1.0 INTRODUCTION .......................................................................................................................1

2.0 TEST SPECIMEN............................................................................................................................................

3.0 TEST SETUP LAYOUT .................................................................................................................

4.0 COMPONENT CHARACTERIZATION TESTS ....................................................................................

5.0 SYSTEM CYCLIC BEHAVIOR ............................................................................................................9

6.0 CONCLUSIONS..................................................................................................................................16

7.0 REFERENCES .........................................................................................................................17 


\section{LIST OF TABLES}

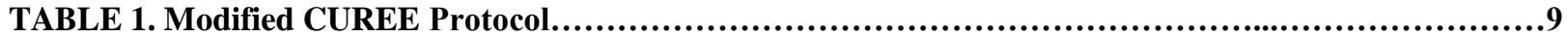

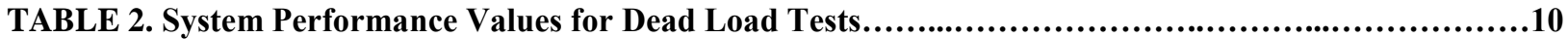

TABLE 3. System Performance Values for Beta Tests............................................................12 


\section{LIST OF FIGURES}

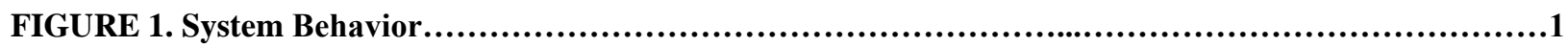

FIGURE 2. Specimen Dimensions................................................................................2

FIGURE 3. Ductile Hold-down...........................................................................4

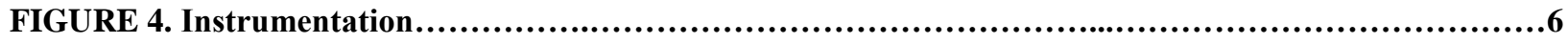

FIGURE 5. Test Setup...................................................................................7

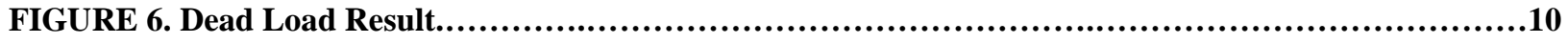

FIGURE 7. UFP Hysteretic...............................................................................11

FIGURE 8. Beta Results.....................................................................................12

FIGURE 9. Heel/Toe Hysteretic.............................................................................13

FIGURE 10. Restoring Force....................................................................................14

FIGURE 11. Load Comparisons.....................................................................15 


\subsection{INTRODUCTION}

The demand for quick construction methods and utilizing more sustainable building materials can be met with mass timber, including utilization of cross laminated timber (CLT). The challenge is to develop building structural systems that also achieve high levels of performance under design level earthquake demands. The focus of this project is on buildings with mass timber structural cores, which often contain stairs or elevators and are the primary lateral load resisting system for the building. Recent developments in rocking CLT shear walls have utilized steel rods to re-center the structure following a seismic event. For reasons of economy and for limiting material creep, this project is developing rocking core walls that utilize floor flexural stiffness and dead load rather than post tensioning.

Rocking behavior along with ductile hold-downs allows for system re-centering and targeted damage to ductile fuses. The rocking wall has an elastic section of its hysterics with a stiffness change as the wall begins to rock as seen in Fig. 1. Ductile hold-down's hysteric is a typical steel yielding behavior with an elastic and post yield stiffness. The combination of these two creates a flagging behavior of the systems hysteretic behavior. Flagging depth can be defined as the percentage from the first yield to the return of the elastic stiffness line, this value is defined as beta ( $\beta$ ) (Fig. 1). Rocking wall behavior and ductile behavior have a beta value of zero and one, respectively. This bounds all test results between zero and two, beta values of less than one are self-centering while values greater than one will have residual drifts.

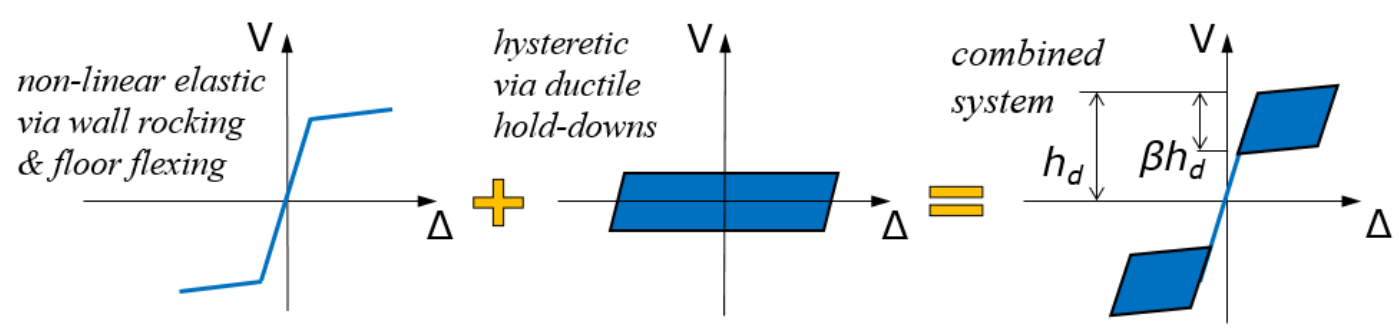

Figure. 1 Additive components of system behavior 


\subsection{SPECIMEN DETAILS}

The test specimen was designed to be reflect a single frame section or bay of a larger structure. This bay consisted of two mass timber columns with a CLT shear wall centered between them and a floor slab resting on both the columns and the shear wall. The overall bay length was $5.46 \mathrm{~m}\left(17^{\prime}-11^{\prime \prime}\right)$ and a height of $3.35 \mathrm{~m}\left(11^{\prime}\right)$ as seen in Fig. 2. The shear wall extended $0.91 \mathrm{~m}\left(3^{\prime}\right)$ from the center line of the bay in each direction, with a height and width aspect ratio of 1.83 , this was selected based off availability of materials and its associated stiffness. A load collector beam was located at center of the of the shear wall to provide a self-centering load and assist in the gravity loads.
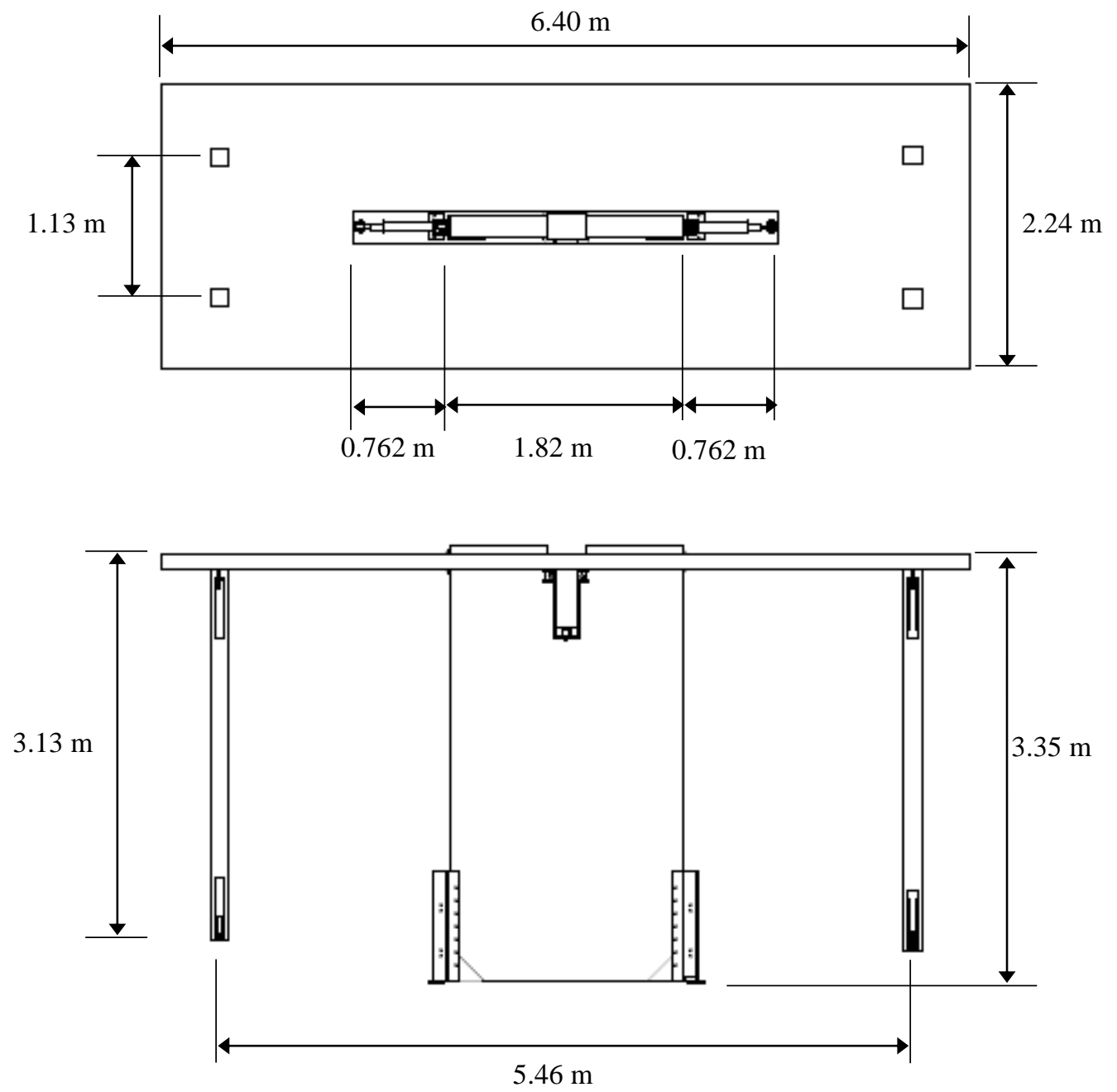

Figure. 2. Plan and elevation views of test specimen

The test specimen consisted of multiple mass timber members along with various steel components. The main members were the CLT shear wall and floor slab, manufactured by KLH. A 5-ply panel was used for the shear wall with a thickness of $162 \mathrm{~mm}(6.375$ "), and a 3-ply panel at a thickness of $108 \mathrm{~mm}$ (4.25") was used for the floors 
slab. The wall was cut down to its dimensions while the floor slab maintained its nominal width of $2.34 \mathrm{~m}\left(7^{\prime}-8^{\prime \prime}\right)$, both panels consisted of timber in the Spruce-Pine-Fur category of the National Design Specification for Wood Construction 2015(NDS). The specimen's columns were four 140mm x 140mm (5.5" x 5.5") with two on each side of the bay spaced at $1.105 \mathrm{~m}\left(3^{\prime}-8\right.$ '). Two columns per side were used in place of one for testing stability purpose, when this bay is implemented to a whole system this lateral stability will not be an issue and the four columns can easily be replaced by one column in line with the shear wall. The load collector beam was a $171 \mathrm{~mm} \times 457 \mathrm{~mm}$ (6.75" x 18") class 24F-1.8E (NDS). Steel components were used as connectors between the timber members.

The specimen was being tested for its lateral performance, therefore the specimens connections needed to account for this and be practical enough that it could be implemented in the field. The columns are modeled as pinned-pinned between the floor slab and foundation. This was achieved by using four Simpson's hold-downs, two on top and two at the base (Fig. 5). There was not a fixed connection between the beam and floor slab, the slab bears on the beam, to ensure the beam could only transfer a load vertically through the bearing(Fig. 5). A beam hanger was used to fix the beam to the wall, similar to Simpson's Strong Tie hangers. The beam was cantilevered and uses the same hold-downs as the columns to develop the tension load at the top of the beam. This will not be necessary when the specimen is implemented in a full scale system because it would be simply supported between two shear walls. The floor slab was connected to the wall through an axial load transfer mechanism, this mechanism was pinned on both ends to resemble a truss member. This load was then transferred to the foundation using nonlinear spring hold-downs that anchors to the foundation.

The hold-downs between the wall and foundation were what allowed the system to undergo rocking behavior and dissipate energy. The hold-downs consisted of two main parts, one that connects to the wall and one connected to the foundation. The wall section used seven $22.2 \mathrm{~mm}(0.875$ ") dowel type fasteners in double shear to connect to the wall. Rocking CLT shear walls traditionally have problems with inelastic crushing of the toe, this was resolved by extending a steel plate underneath the toe to allow for adequate bearing area. The part of the holddown that connected to the foundation used two $25.4 \mathrm{~mm}(1$ ') bolts to create a slip critical connection. The two parts are connected using $U$ flexural plates (UFPs) as seen in Fig 3. These plates allowed for the rocking behavior and the yielding of them provided energy dissipation. Rocking behavior is possible because up lift is allowed due to the lack of rigid connection between the wall and foundation and only between the UFPs that are designed to yield. The UFPs underwent stable symmetric hysteretic behavior which is beneficial in design. 


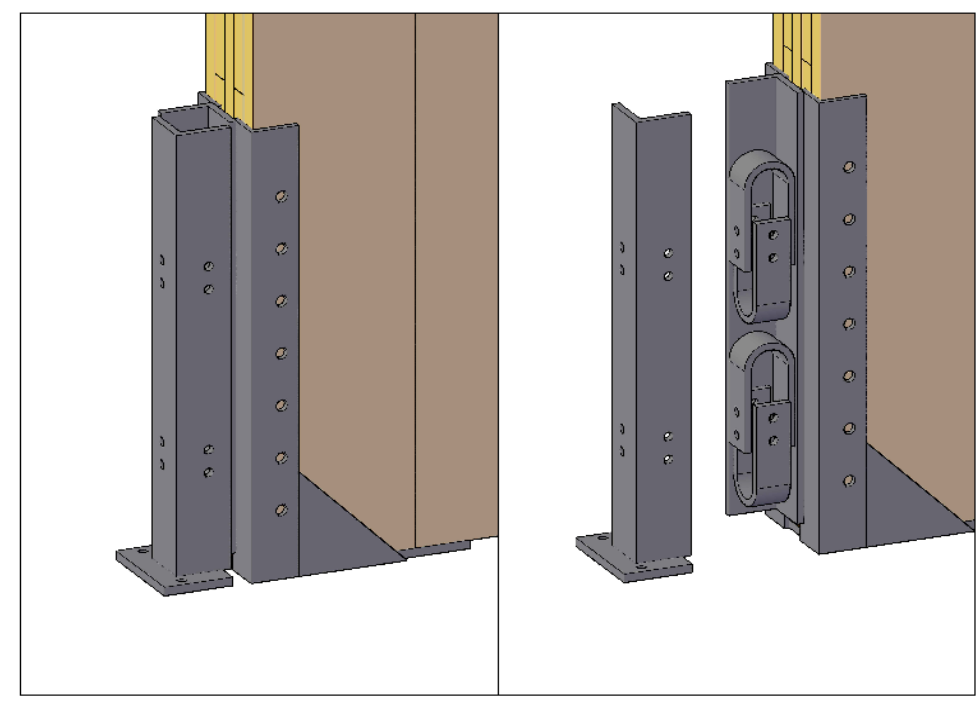

Figure. 3. Foundation and wall assembly with U flexural plates

The lateral force transfer mechanism allowed for the inertial load to be transferred from the floor slab to the shear wall. This mechanism uses a 76.2mm x 76.2mm x 4.76mm (3" x 3" x 0.188 ") HSS section axially loaded to transfer the load. The swivels on either side of the HSS ensured it is only loaded axially. The swivels were connected to the timber using bearing plates with a double shear bolted connection, bearing plates were large enough to prevent crushing of the panels while transferring the load. The length between the connection points was $0.76 \mathrm{~m}\left(2^{\prime}-6\right.$ "), this length reduced the vertical component of the load that is generated from the change in geometry due to the rocking behavior.

Gravity loads played the role in the self-centering of the system and needed to be gathered to the wall through a beam. It was necessary to allow the beam to drift and rotate with the wall to reduce any torsional stress to the beam. This is why the beam hanger was fastened to the wall with no rigid connection between the beam and the floor slab. The hanger was made up of $7.94 \mathrm{~mm}(0.313$ ”) plates with fillet welds all around, and a seat large enough to prevent any crushing of the beam. 


\subsection{TEST SETUP LAYOUT}

The specimen sat on a shake table with casters attached with angles to accommodate to entire length of the bay. Cyclic testing required an applied deformation to the specimen this is traditionally achieved by applying a load at a story until the desired displacement occurs. This process was reversed for this test set-up by bracing the floor slab and an applied deformation of the specimen at the base. The shake table/caster assembly was capable of deformations up to $254 \mathrm{~mm}$ (10") in both directions this corresponded to a story drift of $7.6 \%$.

Instrumentation was placed to correspond with desired measurements, with the purpose of quantifying the rocking behavior of the wall and the lead collector beam used to center the system as depicted in Fig. 4. Global measurements such as displacement and load were also required to describe the systems global behavior. Overall displacement was measured using a string pod measuring the shake table displacement and a Linear Voltage Differential Terminal (LVDT) measured the slip between the floor slab and brace. The difference between the two sensors provided the overall system displacement. System base shear was measured by placing two load cells inline with the lateral load transfer mechanism, these results were be compared with the load cell built into the shake table. Heel uplift of the wall provides information on where the UFPs are in their hysteretic behavior, this uplift was measured using 203mm (8”) stroke LVDTs. Gravity beam loads from dead load and deflection of the floor slab were measured using canister load cells placed under the beam between two bearing plates. Other measured displacements and rotations included component slip, column rotation, and column to slab rotation.

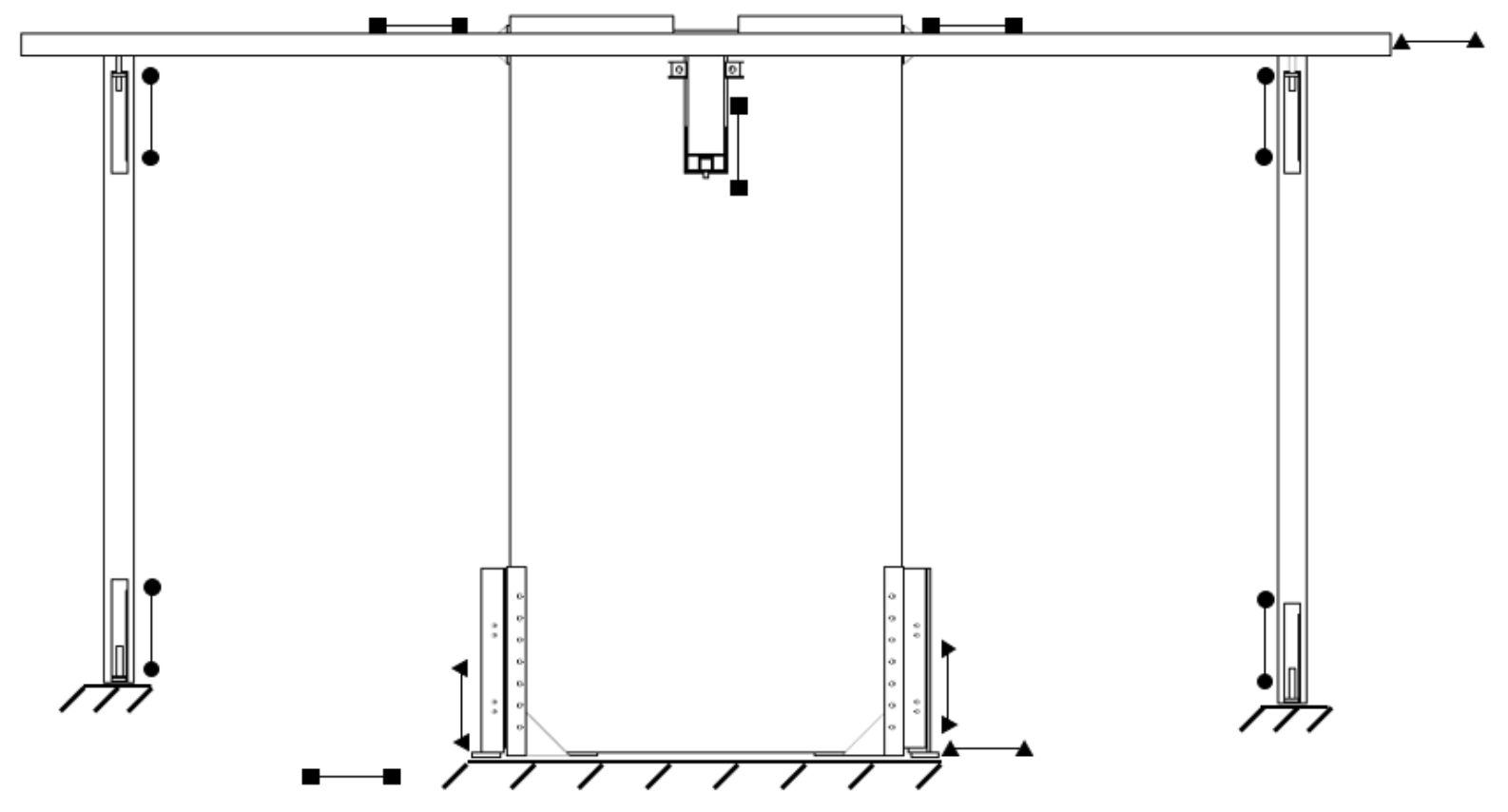


Figure. 4. Instrumentation for cyclic testing, triangle to triangle is deformation, square-square is load, and circle to circle is rotation.

Dead load was used to assist in the self-centering of the system. A $1.53 \mathrm{~m} \times 1.53 \mathrm{~m} \times 0.61 \mathrm{~m}\left(5^{\prime} \times 5^{\prime} \times 2^{\prime}\right)$ concrete block is used along with two $102 \mathrm{~mm}$ (4.5”) thick steel plates, collectively with a weight of $62.3 \mathrm{kN}$ (15kip) as seen in Fig. 5. The weight was connected to the floor slab using threaded rod through the block and an HSS. Angles are welded to the side the HSS with SDS screws fastening the HSS assembly to the slab. This connection was located in the center of the mass block and directly above the load collector beam. The block has rollers on either side, this single connection ensures the block does not contribute stiffness to the floor slab. The threaded rods are also used with angles to create a slip critical connection between the plates and block.

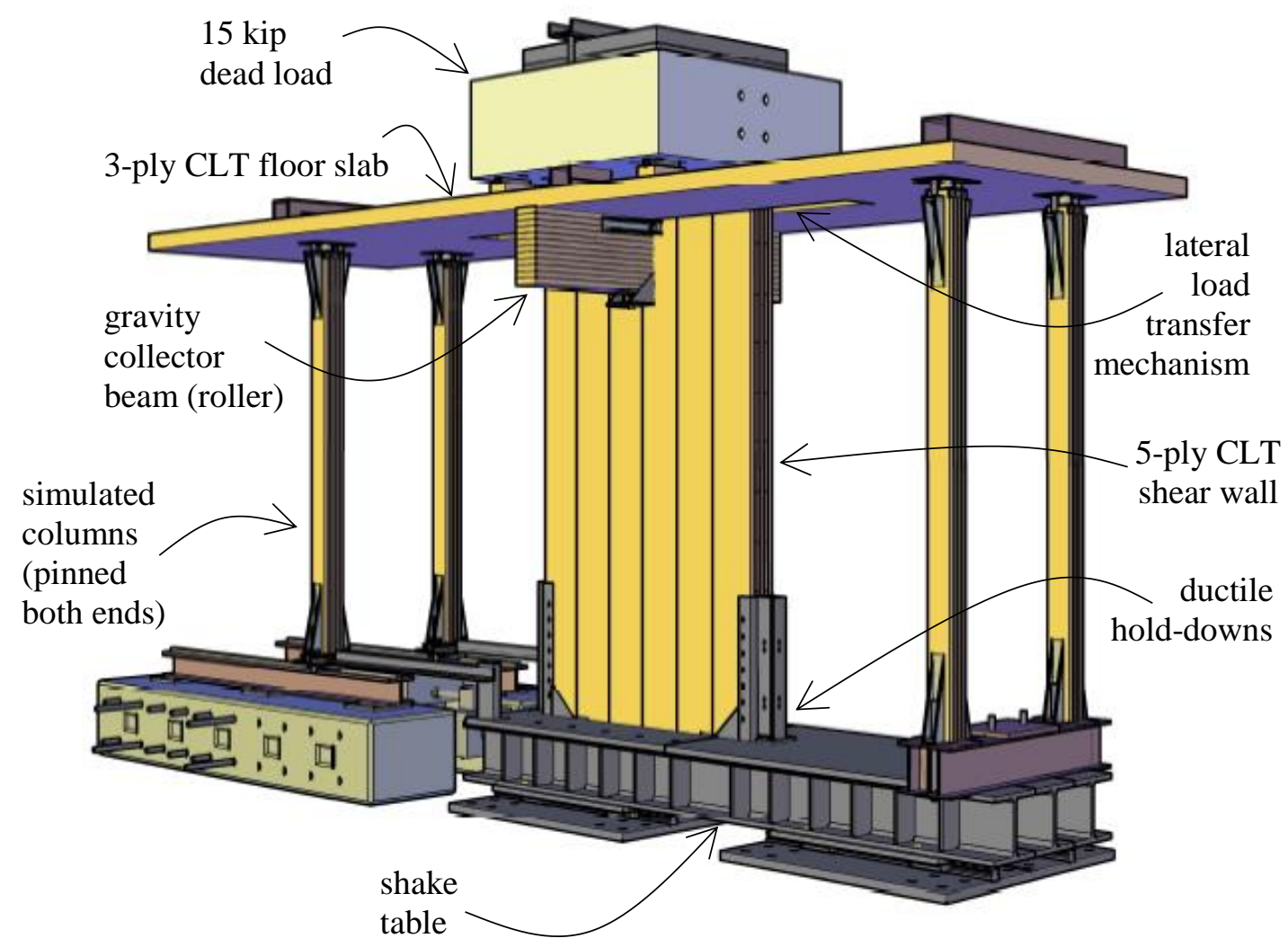

Figure. 5. Full scale test setup 


\subsection{COMPONENT CHARACTERIZATION TESTS}

Preliminary tests provided information on parts of the specimen that are not directly measured in the primary testing sequence. Key information required to help with understanding the results in the primary sequence include the floor slab flexural stiffness and lateral timber frame stiffness. These tests provided information on the expected re-centering load and the additional stiffness added from the timber frame.

Floor slab stiffness tests consisted of two tests, one measured only the stiffness of the slab (Test 1) and the other measured the slab plus the load collector beam stiffness (Test 2). High capacity hydraulic rams were placed where the gravity beams were located to apply load. Deflection was measured at four points two at the location of load and two at the exterior of the floor slab in line with the load. These exteriors displacements provided information on the relative displacement between where the load was applied and the exterior of the slab. The rams had a max stroke of $76.2 \mathrm{~mm}$ (3”), therefore the slab was displaced to $63.5 \mathrm{~mm}(2.5$ ") at the point of loading, and repeated for a total of three cycles. Test 1 provided an average stiffness of 560kN/m (3.2kip/in). The exterior deflection was $57 \%$ of the one at the load, this difference was much larger than the expected difference during testing. For Test 2 the load collector beam was fastened to the floor slab to add its stiffness, this increased the stiffness to $771 \mathrm{kN} / \mathrm{m}$ (4.4kip/in). The difference between the exterior of the slab and at the load was reduced to 93\%. These results reflected estimated values from hand calculations.

Column to foundation and column to slab connections had been assumed pinned. However, this was most likely inaccurate, it was quantified by conducting a pull test on the floor slab with the shear wall disengaged. Instrumentation required for the test included a string pod measuring overall displacement of the floor slab, a LVDT for the slip of the shake table, and a load cell in line and a pulley applied the load. The slab was pulled to a displacement of a $203 \mathrm{~mm}(8 ")$ which corresponded to a drift of $6 \%$. Timber frame stiffness was $39.4 \mathrm{kN} / \mathrm{m}$ (0.225kip/in), large enough to play a role in the lateral stiffness of the system. Reducing the timber frame stiffness was desired and achieved altering the column bases. The column bases were tapered out with a depth of $12.7 \mathrm{~mm}$ $(0.5$ ") and length of $25.4 \mathrm{~mm}(1 ")$. The tapered bases reduced the effective frame stiffness $24.1 \mathrm{kN} / \mathrm{m}(0.138 \mathrm{kip} / \mathrm{in})$. Effective stiffness refers the stiffness associated with the load and displacement at max deflection. However, the results showed a bi-linear behavior rather than a linear one. At $102 \mathrm{~mm}$ (4") of displacement there was a stiffness increase, from 0mm-102mm (0"-4") the stiffness was $17.5 \mathrm{kN} / \mathrm{m}$ (0.1kip/in) while from $102 \mathrm{~mm}-204 \mathrm{~mm}(4 "-8$ ") it was $30.6 \mathrm{kN} / \mathrm{m}(0.175 \mathrm{kip} / \mathrm{in})$. 


\subsection{SYSTEM CYLIC BEHAVIOR}

CUREE Publication No. W-02 provided a loading protocol that has historically been used for timber structures, for consistency this protocol was used for these tests. A reference drift of $3 \%$ was used, this value was chosen because it is 1.5 larger than code maximum of $2 \%$. Modified CUREE was followed, this alters the magnitude of the trail cycles from $75 \%$ of the primary cycle to $100 \%$. Another deviation from the protocol was reducing the number of trailing cycles for second and third sequences from six to three. The specimen underwent thirty-seven total cycles with the final three at a drift of $6 \%$.

Table 1. Modified CUREE Protocol

\begin{tabular}{ccccccccccc}
\hline No. of Cycles & 6 & 4 & 4 & 4 & 4 & 3 & 3 & 3 & 3 & 3 \\
\hline Drift $(\%)$ & 0.015 & 0.23 & 0.30 & 0.60 & 0.90 & 1.2 & 2.1 & 3 & 4.5 & 6 \\
\hline
\end{tabular}

The projects primary goal was researching alternative forms of restoring force then the traditional post tensioned rods. Flexural stiffness of the floor slab was considered the primary supply of this force but effects of dead load should also be investigated. Two tests were conducted, one without a dead load (Frame Only) and the other with a $62.3 \mathrm{kN}$ (15kip) dead load (Frame \& DL). This added load was expected to increase the load of initial rocking motion and the overall max base shear. Theoretical values for the base shear at first uplift were calculated with statics and summing the moments at the toe of the wall, and assuming no load at the heel. Theoretical first uplift values were calculated to be $1.7 \mathrm{kN}(0.382 \mathrm{kip})$ and $19.9 \mathrm{kN}(4.5 \mathrm{kip})$ for frame only and frame \& DL, respectively. Both tests had a change of beam load of $35-40 \mathrm{kN}$ (8-9kip), but the dead load add a constant $56 \mathrm{kN}$ (12.6kip) to the one test as seen in Fig. 6b. This means when the specimen without load is at large displacements it will have less re-entering force then when specimen without load is at zero position. That suggests dead load is the primary supplier of the re-centering force and not the flexural stiffness of the floor slab, for these test setups. The addition of the dead load added a P-delta effect, reducing the post rocking stiffness of the specimen by $27 \%$ (Fig. 6a). The post rocking load for both tests was still increasing load because of the spring load from the floor slab provides stability of the structure at larger displacements. 
Table 2. System Performance Values for Dead Load Tests

\begin{tabular}{cccccccc}
\hline & \multicolumn{2}{c}{ Theoretical } & & \multicolumn{3}{c}{ Experimental } \\
\cline { 2 - 3 } \cline { 6 - 8 } & \multirow{2}{*}{$\mathrm{k}_{\mathrm{e}}$} & uplift & & $\mathrm{k}_{\mathrm{e}}$ & $\mathrm{k}_{\mathrm{u}}$ & uplift & $\mathrm{P}_{\max }$ \\
& $\mathrm{kN} / \mathrm{m}$ & $\mathrm{kN}$ & & $\mathrm{kN} / \mathrm{m}$ & $\mathrm{kN} / \mathrm{m}$ & $\mathrm{kN}$ & $\mathrm{kN}$ \\
& $(\mathrm{kip} / \mathrm{in})$ & $(\mathrm{kip})$ & & $(\mathrm{kip} / \mathrm{in})$ & $(\mathrm{kip} / \mathrm{in})$ & $(\mathrm{kip})$ & $(\mathrm{kip})$ \\
\hline \multirow{2}{*}{ Frame Only } & 9900 & 1.7 & & 825 & 133 & 2.1 & 28.4 \\
& $(56.5)$ & $(0.39)$ & & $(4.7)$ & $(0.76)$ & $(0.47)$ & $(6.4)$ \\
Frame \& DL & 9900 & 19.9 & & 3849 & 97.4 & 17.8 & 42 \\
& $(56.5)$ & $(4.5)$ & & $(21.9)$ & $(0.56)$ & $(4.0)$ & $(9.4)$ \\
\hline
\end{tabular}
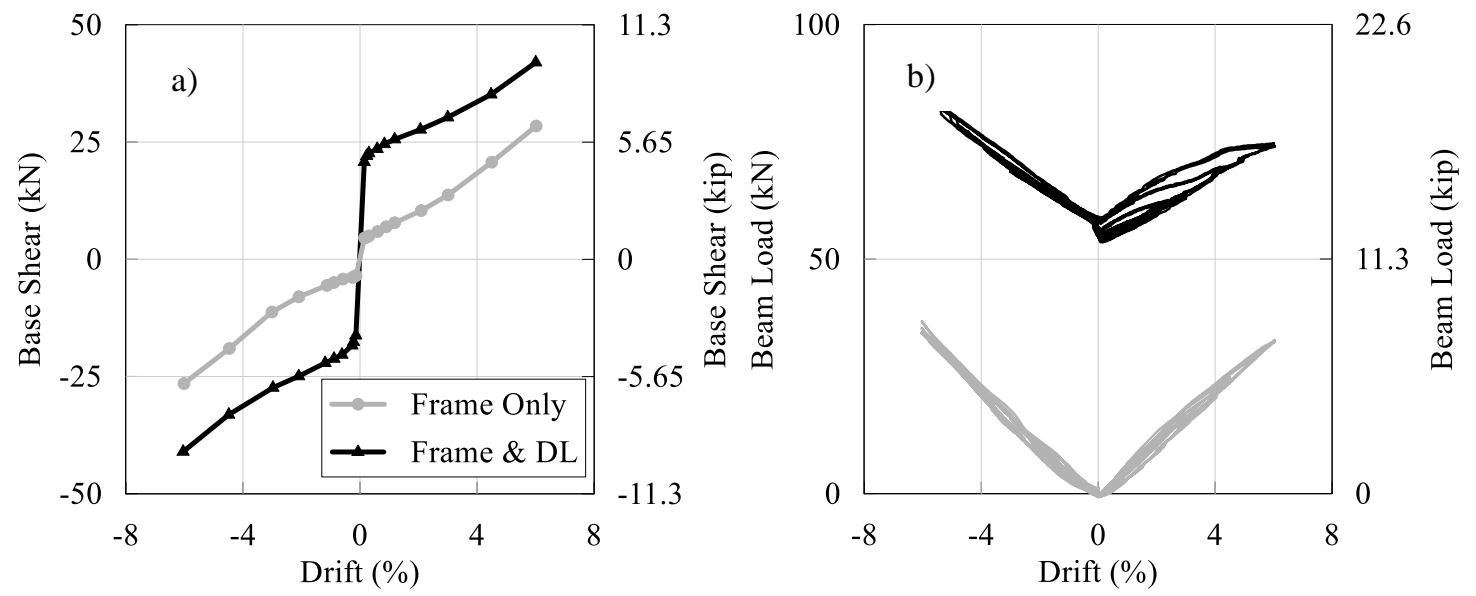

Figure. 6. a) Backbone curves b) Beam restoring force

Inelastic properties of the hold downs allowed for energy dissipation of the system during a seismic event.

The amount of energy dissipation is controlled by the properties and number of U-flexural plates (UFPs). Hysteretic behavior of the UFPs were modeled with an elastic and perfectly plastic behavior depicted in Fig 7, with first yield occurring at $150 \%$ of the plastic force. Assuming first yield occurs at this point provided a conservative prediction for self-centering. This is because the higher yield value is doubled on the return cycle resulting in a deeper flag of the system behavior. The first yield assumption over estimates the energy dissipation of the UFPs. Two UFP geometries were used for the testing, a low capacity and high capacity UFP. The low capacity UFP had a plastic force of $7.0 \mathrm{kN}$ (1.6kip) with a stiffness of $1.9 \mathrm{kN} / \mathrm{mm}$ (10.9kip/in), two and four of these UFPs were used for Tests 1 $\& 2$, respectively. Three high capacity UFPs were used for Test 3 with a stiffness of $13.1 \mathrm{kN} / \mathrm{mm}$ (74.8kip/in) and plastic force of $24 \mathrm{kN}$ (5.4kip). 

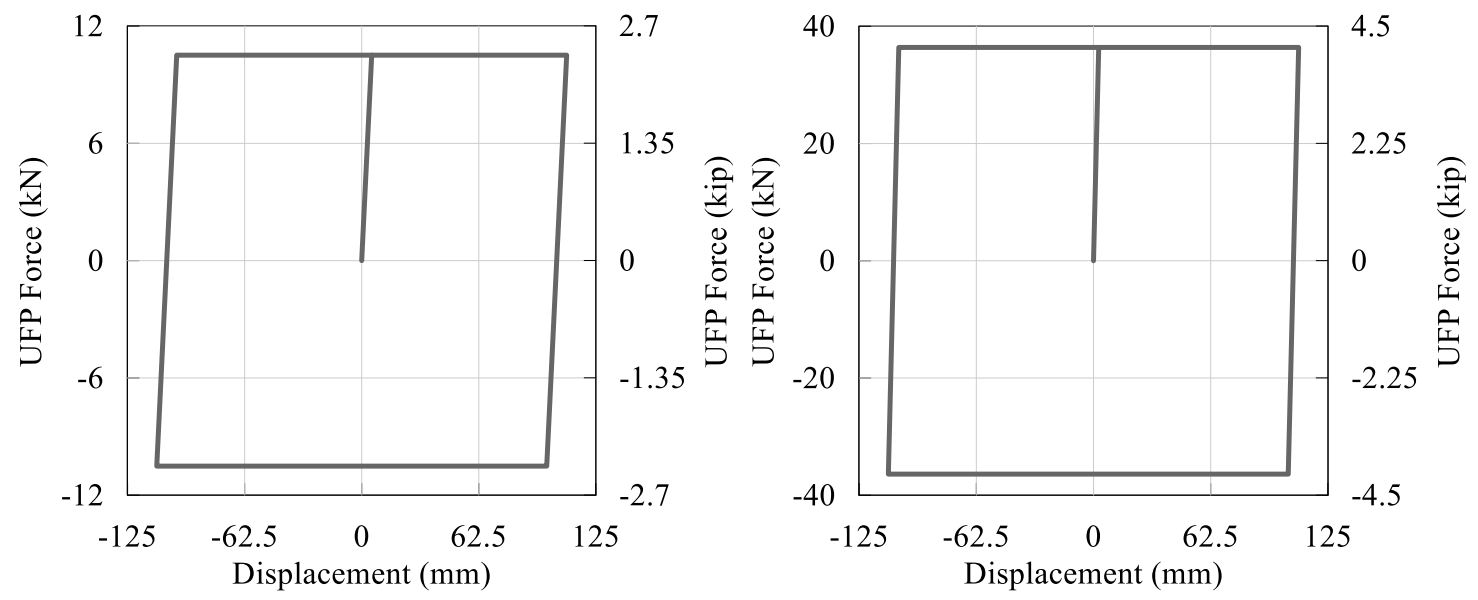

Figure. 7. Assumed hysteretic behavior of a single UFP for Test $1 \& 2$ (left) and Test 3 (right)

Three varying hold down capacity tests, Beta Tests, were conducted Test 1 with a pole and flag behavior $(\beta<1)$, Test 2 demonstrating ideal flagging behavior $(\beta=1)$, Test 3 with no flagging behavior $(\beta>1)$. Push over analysis was done using the performance states of the hold-downs, first uplift of the wall, floor slab stiffness and frame lateral stiffness. The perfectly plastic assumption of the hold-downs results in equal post yield stiffness for all tests, the only additive contribution to the systems post yield stiffness was the floor slab. Expected max load does vary for each test because the yield point of the hold-downs vary, Test 3 theoretical max load is double that of Test 1.

UFPs do not influence the specimen prior to uplift, first uplift load and elastic stiffness for Beta test should be the same as the Frame \& DL test. The experimental uplift loads for all three tests were within $10 \%$ of each other and on average $20 \%$ larger than the Frame \& DL test. The hold-down properties contribute to the rocking stiffness, as the capacity of the hold-down increase so does the rocking stiffness and by result the max base shear of the system increases. Experimental rocking stiffness's were found by using the slope of the backbone curve from drift of $2 \%$ and $4.5 \%$. Rocking stiffness increased by $10 \%$ and 66\% from Test 1 for Test 2 and Test 3, respectively. Max load increased by $23 \%$ and $72 \%$ for Tests 2 and 3, respectively, when compared to Test 1 . The three tests used a total of eighteen UFPs, only two completely fractured. Both fractures occurred during Test 3, one in the first cycle of the $4.5 \%$ drift and the other on the first cycle of the $6 \%$ drift apparent in the backbone cure in Fig. $8 \mathrm{~d}$. The ability to manipulate hold-down properties allows for the control of the global behavior of the system. 
Table 3. System Performance Values for $\beta$ Tests

\begin{tabular}{|c|c|c|c|c|c|c|c|c|c|c|}
\hline \multirow[b]{2}{*}{ Test } & \multicolumn{5}{|c|}{ Theoretical } & \multicolumn{5}{|c|}{ Experimental } \\
\hline & $\beta$ & $\begin{array}{c}\mathrm{k}_{\mathrm{e}} \\
\mathrm{kN} / \mathrm{m} \\
(\mathrm{kip} / \mathrm{in})\end{array}$ & $\begin{array}{c}\mathrm{k}_{\mathrm{u}} \\
\mathrm{kN} / \mathrm{m} \\
\text { (kip/in) }\end{array}$ & $\begin{array}{l}\text { uplift } \\
\text { kN } \\
\text { (kip) }\end{array}$ & $\begin{array}{c}P_{\max } \\
\mathrm{kN} \\
\text { (kip) }\end{array}$ & $\beta$ & $\begin{array}{c}\mathrm{k}_{\mathrm{e}} \\
\mathrm{kN} / \mathrm{m} \\
\text { (kip/in) }\end{array}$ & $\begin{array}{c}\mathrm{k}_{\mathrm{u}} \\
\mathrm{kN} / \mathrm{m} \\
\text { (kip/in) }\end{array}$ & $\begin{array}{l}\text { uplift } \\
\text { kN } \\
\text { (kip) }\end{array}$ & $\begin{array}{c}\mathrm{P}_{\max } \\
\mathrm{kN} \\
\text { (kip) }\end{array}$ \\
\hline 1 & 0.74 & $\begin{array}{c}9900 \\
(56.5)\end{array}$ & $\begin{array}{c}81.4 \\
(0.46)\end{array}$ & $\begin{array}{c}19.9 \\
(4.45)\end{array}$ & $\begin{array}{c}47.8 \\
(10.7)\end{array}$ & 0.77 & $\begin{array}{l}3965 \\
(22.6)\end{array}$ & $\begin{array}{c}110 \\
(0.63)\end{array}$ & $\begin{array}{l}20.3 \\
(4.6)\end{array}$ & $\begin{array}{c}54.6 \\
(12.3)\end{array}$ \\
\hline 2 & 1.07 & $\begin{array}{c}9900 \\
(56.5)\end{array}$ & $\begin{array}{c}81.4 \\
(0.46)\end{array}$ & $\begin{array}{c}19.9 \\
(4.45)\end{array}$ & $\begin{array}{c}59.2 \\
(13.3)\end{array}$ & 1.01 & $\begin{array}{c}4068 \\
(23.3)\end{array}$ & $\begin{array}{c}121 \\
(0.69)\end{array}$ & $\begin{array}{l}22.5 \\
(5.0)\end{array}$ & $\begin{array}{c}67.2 \\
(15.1)\end{array}$ \\
\hline 3 & 1.49 & $\begin{array}{l}9900 \\
(56.5)\end{array}$ & $\begin{array}{c}81.4 \\
(0.46)\end{array}$ & $\begin{array}{c}19.9 \\
(4.45)\end{array}$ & $\begin{array}{c}95.8 \\
(21.5)\end{array}$ & 1.34 & $\begin{array}{l}4237 \\
(24.2)\end{array}$ & $\begin{array}{c}182 \\
(1.0)\end{array}$ & $\begin{array}{l}21.9 \\
(4.9)\end{array}$ & $\begin{array}{c}94.3 \\
(21.1)\end{array}$ \\
\hline
\end{tabular}
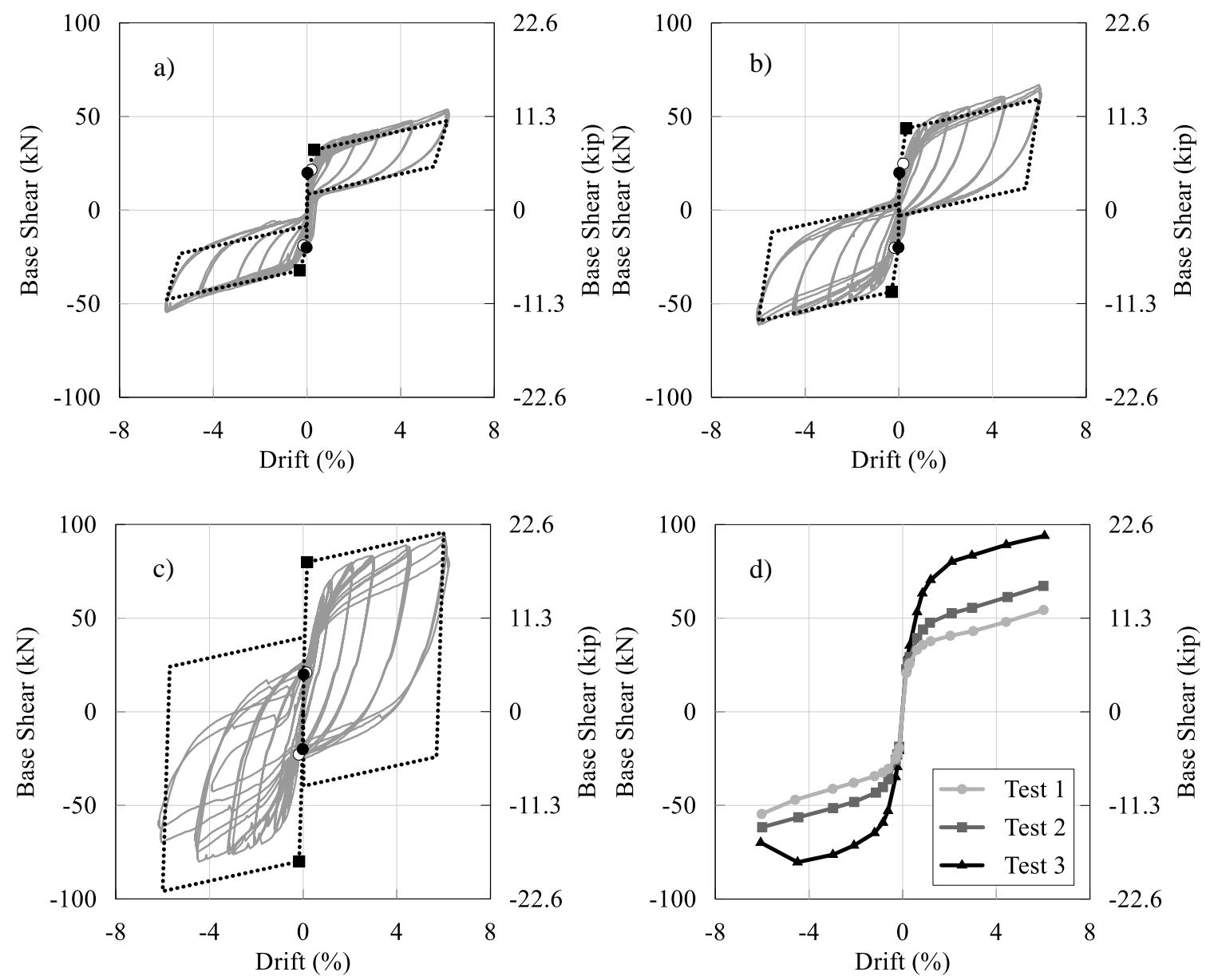

Figure. 8 Experimental hysteric curve (solid) with first uplift (white circle) and theoretical overlay (dotted) with first uplift and hold-down yield(black circle and square) for a) Test 1, b) Test 2, and c) Test 3. d) comparison of backbones 
The measurements of base shear and beam loads can be used with statics to determine the heel and toe forces throughout the test. By summing the moments at either the heel or toe the reaction at opposite corner of the wall can be found. This was beneficial for determining load on the heel and toe of the wall, and see if the toe of the wall will undergo crushing. Toe force was always be greater than heal force because the toe incorporates the moment couple with the heel and the gravity loads of the system, depicted in Fig. 9. The sum of both heel and toe forces was always be equal to the dead load and flexural load from the floor slab. This is measured by the load collector beam.
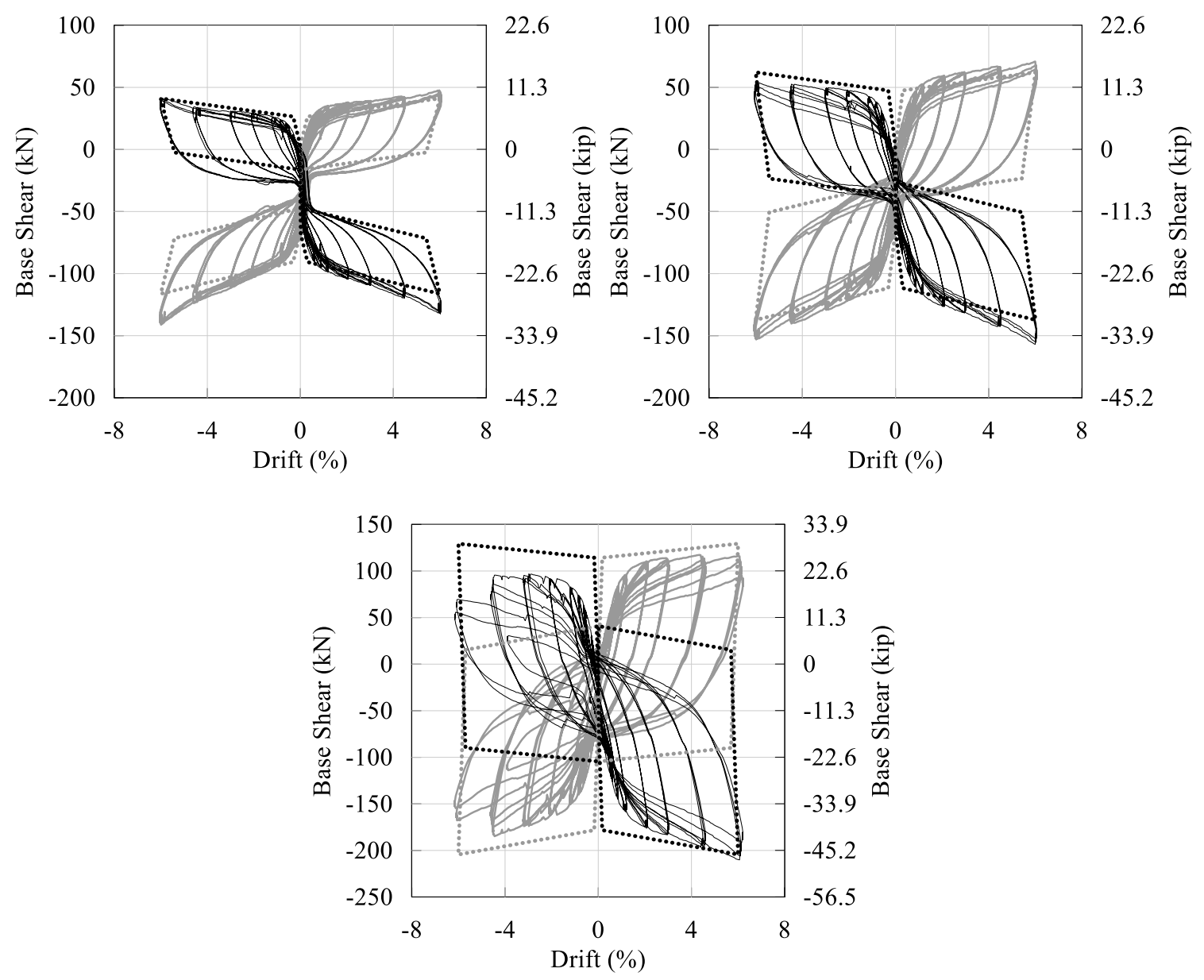

Figure. 9 Heel-Toe Forces for beta tests. Positive values are tension loads and negative are compression.

Beam load was independent of hold-down properties results of the beam restoring force are expected to be similar for all Beta tests. This was because the load cell under the beam only measures the force from the dead load and the added load from the flexing of the floor panel. All Beta tests had a change in beam load of between 35- 
40kN (8-9kip), seen in Fig. 10. The data showed slip in the beam for positive drifts, this could have been due to the lack of rigid connection between the beam and floor slab.
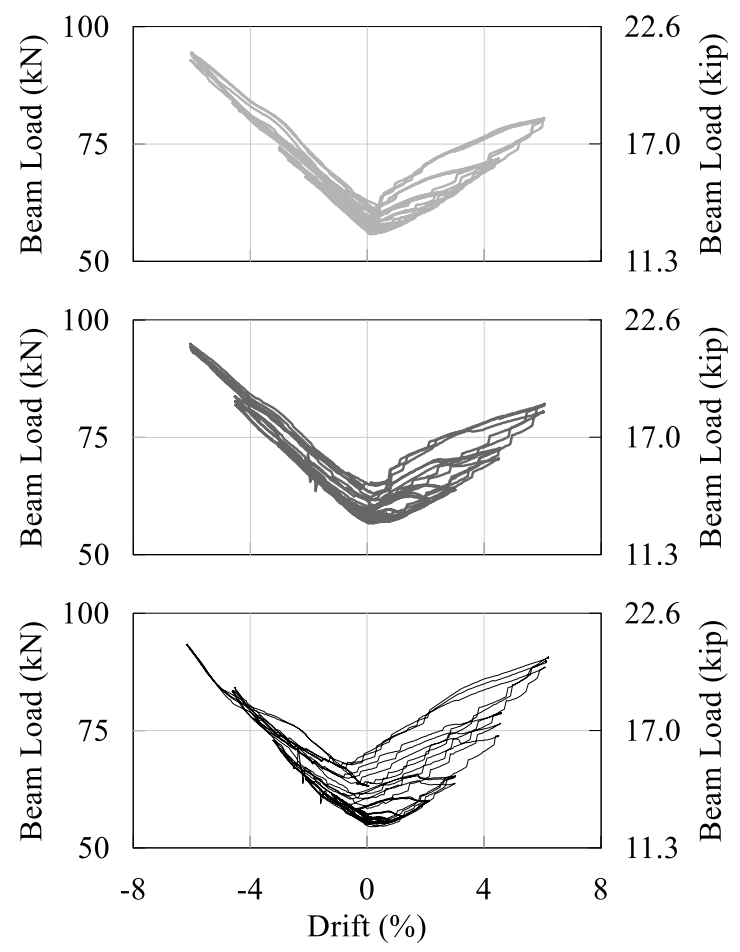

Figure. 10 Beam restoring force for Test 1-3 form top to bottom

Load transfer mechanisms were intended to be the only later force transfer of the system and was instrumented with load cells because of that. However, friction force between the beam and floor slab allowed another load path. This was discovered when comparing the hysteretic behavior using the lateral transfer mechanism and the shake table load cell (Fig. 11). The hold-downs are intended to remain elastic except for the UFPs, this was not the case as the specimen underwent larger drifts. Large drifts began to yield the part of the holddown that anchors to the foundation, allowing for the UFPs to stretch and cause an increase in radius. As the radius of the UFPs increase the stiffness decreases. This is seen in the large drift cycle in Fig. 8c, the trailing cycles had less load then the primary cycle due to the reduced stiffness. 


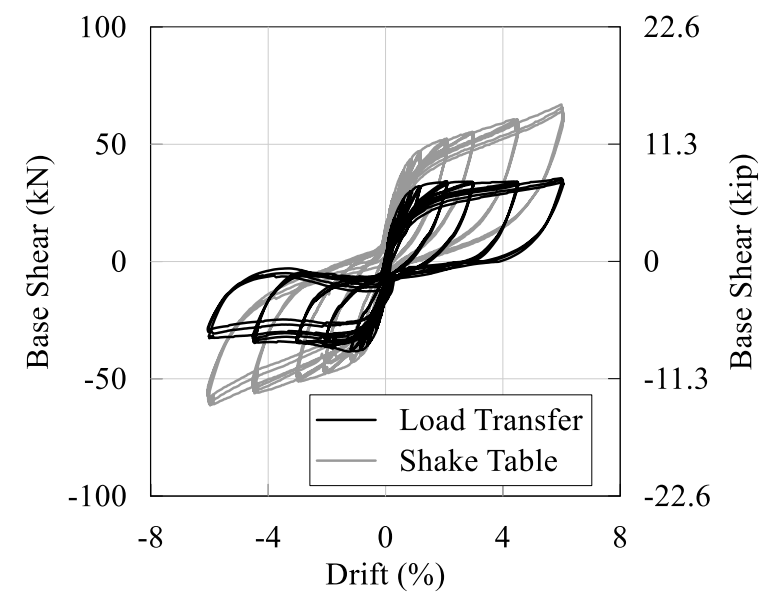

Figure. 11 Hysteretic comparison between load cells 


\subsection{CONCLUSIONS}

The floor restoring system proved viable as a self-centering system, behavior of the system is predictable and can accommodate large drifts. System behavior can be modified by altering the hold-down properties, to represent desired energy dissipation. Dead load contributed $80 \%$ of the restoring force at the target drift of 3\%. This can cause problems in implementation if dead loads are different than originally expected, because the system is intended to re-center but if there is inadequate dead load the systems lateral strength and stiffness can suffer. Changes in geometry due to rocking behavior causes design difficulties, because components are required to accommodate the later displacement and the added rotation due to the rocking behavior.

Future research can explore potential options of making the floor flexure a larger contributor in the restoring force. Changing the bay length to increase the floor slab stiffness is a potential option, or the use of a thicker floor slab. The thicker floor slab may also allow for more dead load that along with the increased stiffness can allow for more energy dissipation with the ability to use higher capacity UFPs. 


\subsection{REFERENCES}

American Wood Council. "NDS Supplement, National Design Specification Design Values for Wood Construction." Leesburg, VA, 2015 
8.0 